\title{
PENGELOLAAN HUTAN PULAU SEHO SEBAGAI MODEL KONSERVASI PULAU KECIL DI KABUPATEN PULAU TALIABU
}

\author{
${ }^{1}$ Murianto Wenno*, ${ }^{2}$ Agustinus Kastanya, ${ }^{3}$ Iskar ${ }^{1}$ \\ Program Studi Agroforestry, Politeknik Perdamaian Halmahera J1. Raya Tobelo-Galela, Telp. \\ (0924) $21572{ }^{2,3}$ Program Studi Manajemen Hutan, Pascasarjana Universitas Pattimura Ambon \\ Jl. Dr.Ir. M. Latumeten, Kampus PGSD - Ambon 57131 \\ *Penulis Korespondensi E-Mail : murianto_wenno@yahoo.com
}

Diterima : 15 Februari 2016 Disetujui : 12 Mei 2016

\begin{abstract}
Intisari
Hutan Pulau Seho saat ini sudah mengalami kerusakan. Kerusakan ini sebagian besar diakibatkan oleh adanya aktifitas masyarakat yang tinggal di dalam dan sekitar kawasan, yang sering melakukan kegiatan seperti penebangan hutan, perburuan satwa liar, serta perladangan berpindah. Aktivitas ini juga didukung oleh akses masyarakat yang mudah masuk ke dalam kawasan hutan. Aktifitas masyarakat merupakan ancaman yang dapat mengganggu keberadaan jenis flora dan fauna yang ada pada kawasan tersebut. Agroforestry adalah suatu sistem pemanfaatan lahan dengan mengkombinasikan berbagai tanaman perkebunan, dan kehutanan. Tujuan dari penelitian ini adalah mengkaji pengelolaan Pulau Seho dengan pendekatan zonasi serta melakukan kolaborasi pengelolaan dengan multi pihak. Penelitian ini termasuk penelitian kualitatif, menggunakan metodologi studi kasus. Pemilihan sampel (informan kunci) dilakukan secara sengaja (purposive sampling), dengan mengambil sampel responden secara purposive sampling sebanyak $30 \mathrm{KK}$. Hasil penelitian menunjukkan bahwa kawasan Pulau Seho dikelola dengan pendekatan zonasi yaitu 1. Zona inti yang merupakan kawasan cagar alam Pulau Seho, 2. Zona Penyangga yang merupakan kawasan disekeliling kawasan inti (wilayah Cagar Alam), yang umumnya terdapat kebun agroforestry masyarakat khususnya tanaman cengkeh dan tanaman kehutanan lainnya, 3. Zona Transisi/Pembangunan Lestari adalah merupakan wilayah di luar kawasan penyangga pada lahan masyarakat, pantai dan pesisir, dimana aktifitas ini ditujukan untuk pengembangan ekonomi masyarakat dan pembangunan ekonomi daerah. Disamping itu, kegiatan kolaborasi antar multi pihak merupakan keharusan dalam pengeloaan kawasan cagar alam Pulau Seho.
\end{abstract}

Kata kunci : Agroforestri, Cagar alam, Kolaborasi, Pulau Seho, Zonasi.

\section{Abstract}

Forest area of Seho island was damaged. Mostly caused by the activities of people who live in and around the area. The activities were logging, wild animal hunting, as well as shifting cultivation. This activity is also supported by the community easy access into the forest. Community activities are threats to the existence of flora and fauna in the region. Agroforestry is a land use system by combining a variety of agricultural crops and forestry. The purpose of this study is to examine management of Seho Island with zoning approach and conduct management of multi-party collaboration. This study included a qualitative study, using the case study methodology. Selection of the sample (key informants) done intentionally (purposive sampling), by taking a sample of respondents by purposive sampling as many as 30 families. The results showed that managed Seho Island neighborhood zoning approach, namely 1. The core areas Seho Island nature reserve, 2. Buffer areas which is the area surrounding the core region (region Nature Reserve), which is generally found agroforestry plantation society, especially Plant cloves and Other forest plants, 3. Transition areas / Sustainable Development is an area outside the buffer zone on the public lands, beaches and coast, where the activity is intended for community economic development and regional economic development. In addition, the activities of multi-party collaboration is a necessity in the management of conservation areas Seho Island.

Keywords: Agroforestry, Collaboration, Management, Nature Reserve, Seho Island, Zoning 


\section{PENDAHULUAN}

Maluku Utara merupakan salah satu Propinsi di Indonesia yang memiliki banyak pulau kecil. Pulau-pulau tersebut kaya akan sumber daya alamnya, termasuk sumber daya hutan dan sudah merupakan sumber kehidupan bagi masyarakat dalam memenuhi kebutuhannya. Namun pulau-pulau kecil tersebut selalu rentan terhadap ancaman kerusakan, baik itu kerusakan yang disebabkan oleh alam maupun kerusakan akibat ulah manusia. Menurut Ozsaer (2006), hal ini didasarkan atas karakteristik pulau yang lebih rentan terhadap degradasi. Sifat pulau dengan DAS yang pendek tentunya membutuh-kan pendekatan pengelolaan berbasis pulau dengan penutupan yang harus lebih besar dibandingkan daerah kontinental dengan pendekatan DAS.

Secara administratif Pulau Seho berada di wilayah pemerintahan Kabupaten Pulau Taliabu Provinsi Maluku Utara. Pulau Seho memiliki hutan seluas 3.908,28 ha dengan sebagian kawasan hutannya sudah dilindungi, yang mana kawasan tersebut telah ditetapkan sebagai Kawasan Konservasi Cagar Alam Pulau Seho berdasarkan SK Menteri Pertanian Nomor 492/Kpts/Um/10/72, tanggal 14 Oktober 1972, dengan luas kawasan cagar alam yaitu 1.250 ha. (BKSDA Maluku, 2013).

Berdasarkan peta tutupan lahan Pulau Seho, dapat dilihat bahwa hampir sebagian besar luas hutan Pulau Seho sudah merupakan areal yang tidak berhutan. Ini mengindikasikan bahwa kondisi hutan Pulau Seho saat ini sudah mengalami kerusakan. Akses masyarakat yang mudah masuk ke dalam kawasan hutan merupakan permasalahan yang patut untuk diperhatikan guna mencegah terjadinya kerusakan hutan. aktifitas masyarakat seperti penebangan kayu secara ilegal, perburuan satwa liar, pembukaan areal hutan untuk berkebun serta adanya sistem perladangan berpindah merupakan masalah-masalah yang mengancam kelestarian hutan Pulau Seho. Selain itu, tingkat ekonomi dan pendidikan masyarakat yang rendah serta pemahaman masyarakat yang kurang tentang pentingnya hutan juga menjadi ancaman bagi kelestarian hutan Pulau Seho. Menurut Siregar (2008) bahwa sebagai entitas yang memilki kecirian khusus, pengelolaan pulau kecil memerlukan format yang sedikit berbeda dengan wilayah regional lain, khususnya yang ada didaratan (mainland). Selanjutnya Kastanya (2006) mengatakan bahwa karakter dan ciri pulau- pulau kecil adalah memiliki kondisi biogeofisis dan sosial-ekonomi mayarakat yang bervariasi; memiliki daerah pantai dan lautan yang luas; memiliki keterkaitan dan saling mempengaruhi antara ekosistem terdekat; pulau kecil dengan topografi bergelombang sampai bergunung membentuk DAS ukuran sempit.

Strategi kebijakan pengelolaan hutan untuk mengelola hutan Pulau Seho sebagai model konservasi pulau kecil dengan pendekatan zonasi. Dalam penelitian ini terdapat 3 zonasi, antara lain : Zona Inti (Core area) adalah kawasan Cagar Alam, yang tidak diganggu oleh kegiatan manusia (undisturbed core area). Hanya kegiatan penelitian, pendidikan, pelatihan dan monitoring. Zona Penyangga (buffer area) adalah wilayah di sekeliling zona inti atau wilayah Cagar Alam. Zona Transisi atau kawasan pembangunan lestari (transition area or sustainable development area) adalah wilayah di luar kawasan penyangga pada lahan masyarakat serta pantai dan pesisir.

Aktivitas ini ditujukan untuk pengembangan ekonomi masyarakat dan pembangunan ekonomi daerah (BKSDA Maluku, 2013). Oleh karena itu, tujuan dari pembuatan zona inti, zona penyangga dan zona transisi/rehabilitasi dalam penelitian ini adalah untuk melindungi kawasan konservasi Cagar Alam Pulau Seho dari ancaman kerusakan hutan, terutama yang dilakukan oleh masyarakat sekitar hutan Pulau Seho.

Berdasarkan permasalahan diatas, maka beberapa permasalahan yang diangkat dalam penelitian ini antara lain (1) bagaimana potensi biotik hutan Pulau Seho? (2) bagaimana kondisi DAS yang ada pada Pulau Seho? (3) bagaimana alternatif strategi pengelolaan hutan Pulau Seho sebagai model konservasi pulau kecil? (4) bagaimana prioritas strategi pengelolaan hutan Pulau Seho? . Untuk menjawab permasalahan, maka ditetapkan tujuan dari penelitian ini adalah untuk (1) mengetahui potensi yang ada di dalam hutan Pulau Seho; (2) menganalisis karakteristik DAS yang ada pada Pulau Seho; (3) merumuskan alternatif strategi dan menentukan prioritas strategi pengelolaan hutan Pulau Seho.

\section{METODE PENELITIAN}

\section{Lokasi dan Waktu Penelitian}

Penelitian ini dilakukan pada Hutan Pulau Seho, di Kabupaten Pulau Taliabu Provinsi Maluku Utara. Penelitian tersebut berlangsung selama 3 bulan, yaitu pada bulan Agustus sampai Oktober 2013. 


\section{Pengumpulan Data}

Data dalam penelitian ini terbagi dua yaitu data primer dan data sekunder. Data primer diperoleh langsung di lapangan, di mana data potensi kawasan diperoleh melalui kegiatan inventarisasi. Sedangkan data ekonomi dan sosial budaya masyarakat diperoleh dari data kuisioner hasil kegiatan wawancara dengan masyarakat serta data hasil wawancara dengan informan kunci. Untuk data sekunder diperoleh melalui literatur-literatur yang berhubungan dengan penelitian

\section{Analisis Data}

Metode analisis data yang digunakan dalam penelitian ini adalah metode analisis deskriptif. Data yang telah diperoleh selanjutnya dikumpul-kan dan diolah dengan cara tabulasi data dan kemudian dianalisis sesuai dengan tujuan penelitian. Analisis data yang dipergunakan adalah analisis Spasial, analisis SWOT dan analisis QSPM.

\section{Analisis Spasial DAS Pulau Seho}

Proses pembuatan peta rencana kelola Pulau Seho dilakukan dengan menggunakan aplikasi Sistem Informasi Geografis (SIG) dengan perangkat lunak Arc Gis Ver. 10.1. Tahap awal pemrosesan dilakukan dengan mengimport data SRTM (Shuttle Radar Topographic Mission) dalam format raster dan data tutupan lahan $P$. Taliabu hasil interpretasi citra satelit Landsat 8 dalam format vektor. Tahapan selanjutnya, melakukan proses pemotongan (clipping) sesuai dengan wilayah kajian. Proses ini bertujuan untuk mendapatkan data areal yang akan dilakukan analisis guna keperluan pemetaan. P. Taliabu hasil interpretasi citra satelit Landsat 8 dalam format vektor. Tahapan selanjutnya, melakukan proses pemotongan (clipping) sesuai dengan wilayah kajian. Proses ini bertujuan untuk mendapatkan data areal yang akan dilakukan analisis guna keperluan pemetaan.

\section{Analisis SWOT}

Untuk merumuskan strategi pengelolaan hutan Pulau Seho akan dianalisis dengan menggunakan metode analisis SWOT. Metode ini bertujuan untuk mengidentifikasi berbagai faktor internal dan eksternal secara sistematis yang hasilnya akan digunakan dalam perencanaan pengelolaan untuk merumuskan strategi pengelolaan hutan Pulau Seho. Model-model analisis yang dipakai dalam mengolah data-data yang telah terkumpul adalah matrik IFAS dan matrik EFAS, sedangkan untuk menganalisis hasil pengolahan data tersebut digunakan model matrik IE dan matrik SWOT.

\section{Analisis QSPM}

Setelah analisis SWOT dibuat dan dianalisa, maka tahap selanjutnya disusunlah daftar prioritas yang harus diimplementasikan. Quantitatif Strategis Planning Matrix (QSPM) merupakan teknik secara objektif dapat menetapkan strategi alternatif rank diprioritas-kan. Langkahlangkah dalam tahapan pengambilan keputusan dengan QSPM adalah membuat daftar peluang dan ancaman dari faktor eksternal dan kekuatan serta kelemahan dari faktor internal.

\section{HASIL DAN PEMBAHASAN}

\section{Potensi Vegetasi dan Satwa}

Hasil inventarisasi yang dilakukan pada ekosistem hutan dataran rendah ditemukan beberapa jenis vegetasi yang menyusun struktur hutan Pulau Seho seperti Damar (Agathis sp), Gamilu, Gamaelo (Cryptocarya sp), Kahamo (Mastixiodendron panchyclados ), Kayu ambon/Matoa (Pometia pinnata), Kayu Hosa (Lixe sp), Kayu Putih (Eucalyptus sp), Meranti Putih (Shorea $s p$ ), Meranti Merah (Shorea selanica), Sengon Merah (Albizia sp), Sengon (Albizia falcataria), Sengon Putih (Albizia sp), Palapi (Heritiera sp), Gondal (Ficus variegata), Kayu Merah (Baccaurea sp), Kamiha (Eugenia $s p)$. Selain itu ditemukan juga jenis Rotan (Calamus sp). Sedangkan hasil inventarisasi yang dilakukan pada ekosistem hutan pantai ditemu-kan alternatif strategi dan menentukan prioritas strategi pengelolaan hutan Pulau Seho.kan jenisjenis vegetasi seperti jenis Kayu kira-kira (Xylocarpus granatum),Ketapang (Terminalia catappa), Katang-katang pantai (Ipomea pescaprae), Beringin (Ficus benjamina), Kayu besi pantai (Intsia bijuga), Kedondong pantai (Spondias sp), Kayu tarabe/Pulaka (Duabanga moluccana), Hutung, Pandan (Pandanus sp),

Pakis ( Asplenium nidus), Keladi Hias (Xanthosoma $s p$ ), Suring (Toona sureni), Kelapa Cocos nucifera), Kenari (Canarium sp), Bintanggur Pantai (Calophyllum sp) dan Waru (Hibiscus tiliaceus).

Hasil inventarisasi jenis fauna baik burung dan mamalia diperoleh lewat wawancara dengan masyarakat, pengenalan suara, lewat sarang dan jejak kaki yang terdapat di hutan Pulau Seho, antara lain: Babi Rusa (Babyrousa babyroussa), Burung Gosong/Maleo (Megapodius bernsteinii), jenis Pombo hutan (Ducula bicolor), Babi Hutan ( Sus scrofa), Rusa ( Cervus 
timorensis), Lembukong/Rangkong (Rhyticeros plicatus), Kakatua (Cacatua alba), Elang

(Haliastur indus), Serak Taliabu (Tyto nigrobrunnea) dan Perkici Kuning Hijau (Trichoglassus flavoviridis Wallace). Sedangkan menurut pengakuan masyarakat yang ada dan tinggal disekitar hutan Pulau Seho, jenis satwa seperti babi, rusa dan babi rusa yang merupakan jenis satwa yang sering diburu oleh masyarakat setempat

Potensi Ekonomi dan Sosial Budaya Kehidupan masyarakat di Pulau Seho pada

umumnya hampir sama, baik itu mata pencaharian maupun tingkat pendidikan. Umumnya masyarakat di Pulau Seho memiliki mata pencaharian utama adalah bertani. Tanaman pertanian yang banyak dimanfaatkan oleh masyarakat sekitar kawasan berupa umbiumbian, kelapa, durian, langsat dan cengkeh. Selain jenis-jenis tanaman pertanian, ada juga jenis tanaman kehutanan yang sering dimanfaatkan oleh masyarakat sekitar, berupa damar, kayu meranti, sengon, lenggua. Semua jenis ini dimanfaatkan untuk memenuhi kebutuhan hidup mereka, seperti untuk dikonsumsi dan untuk membangun rumah atau untuk dijual yang nantinya hasil penjualan dapat dipakai untuk memenuhi kebutuhan lainnya. penjualan dapat dipakai untuk memenuhi kebutuhan lainnya.

Zaman dahulu ada tempat upacara adat di Pulau Seho yang dianggap sebagai tempat pamali. Namun sejalan dengan berkembangnya zaman, tempat tersebut sudah tidak ada lagi. Tempat upacara ini biasanya dipakai selain untuk upacara adat, juga untuk menyimpan alat-alat seperti tombak, parang dan lain sebagainya. Di Pulau Seho masyarakat masih menerapkan sistem perladangan berpindah. Biasanya jika ada keluarga yang meninggal, masyarakat akan pindah dan mencari lahan baru, selain itu juga mengikuti siklus 3-4 tahun baru pindah lahan.

Secara adat lahan baru yang akan dibuka, biasanya dilakukan upacara adat dengan memberikan makan hutan dengan siri dan pinang, dan selanjutnya lahan tersebut dibersihkan atau dibuka. Selain itu sosial masyarakat adat yang ada pada Pulau Taliabu juga sudah mulai terbuka pada masyarakat luar. Hal ini dapat dilihat dengan sudah mulai adanya masyarakat pendatang yang sudah mulai mendiami pulau Taliabu.

\section{Pengelolaan Hutan Pulau Seho Berbasis DAS}

Hasil overlay peta tutupan lahan, peta kelerengan, peta ketinggian, peta DAS, serta peta zonasi Pulau Seho, maka diperoleh peta gabungan antara peta DAS dan peta zonasi Pulau Seho. Hasil analisis ditemukan 28 DAS pada Pulau Seho dengan karakteristik dan luasan yang berbedabeda, dimana terdapat 11 DAS dengan luas $<100$ ha, 12 DAS dengan luas 100 - 200 ha, dan 5 DAS yang sedikit lebih besar dengan luas > 200 ha . Setiap DAS tersebut memiliki karakteristik yang berbeda baik itu kelerengan, ketinggian maupun tutupan lahannya.

Dari segi tutupan lahan, DAS di Pulau Seho lebih didominasi oleh kebun campuran dengan luas 3276,0 ha. DAS-DAS dengan luas < 100 ha memiliki tutupan lahan adalah kebun campuran dengan luas 582,1 ha atau sebesar 91,6\% dan hutan mangrove dengan luas 53,3 ha atau sebesar $18,4 \%$. Sedangkan DAS-DAS dengan luas $100-$ 200 ha didominasi oleh kebun campuran dengan luas 1457,72 ha atau $90,5 \%$, hutan dengan luas 73,1 ha atau $4,5 \%$ serta hutan mangrove dengan luas 77,0 ha atau $4,8 \%$. Selain itu juga terdapat

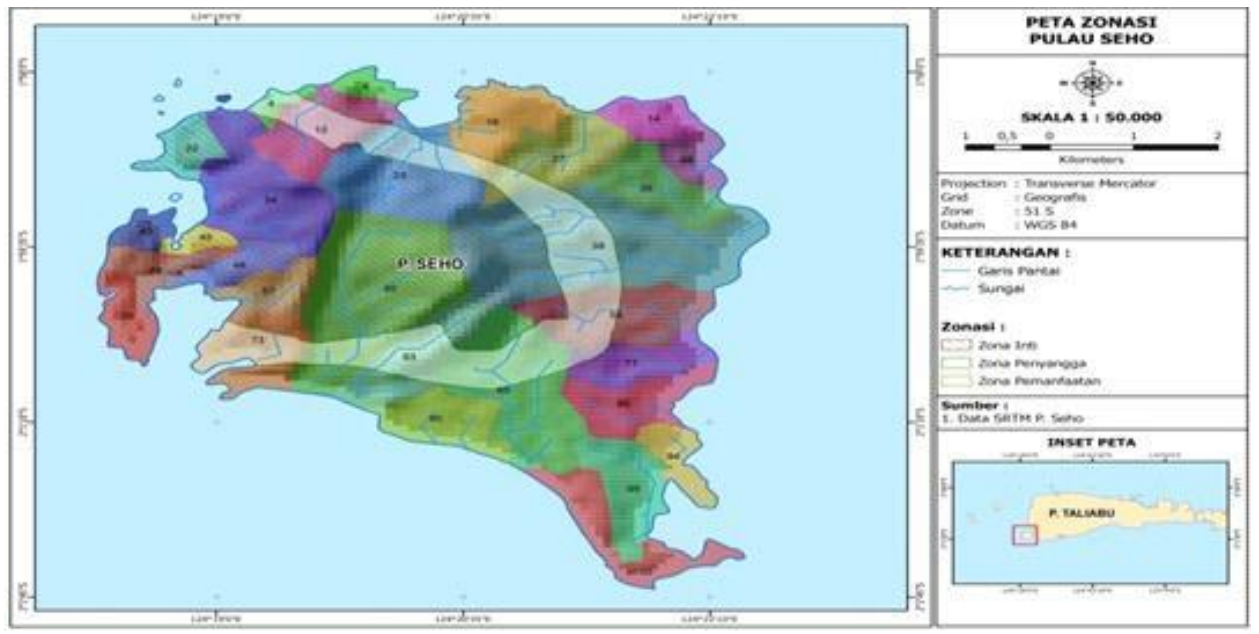

Gambar 1. Peta DAS dan Zonasi Pulau Seho 
Tabel 1. Luas Tutupan Lahan Pulau Seho Berdasarkan Kelas Lereng

\begin{tabular}{cccc}
\hline Nomor & Kelas Lereng & Keterangan & Luas (Ha) \\
\hline 1 & $<8 \%$ & Datar & 931.0 \\
2 & $8-15 \%$ & Landai & $1,132.5$ \\
3 & $15-25 \%$ & Agak Curam & $1,290.7$ \\
4 & $25-40 \%$ & Curam & 448.2 \\
5 & $>40 \%$ & Sangat Curam & 103.9 \\
\hline & Jumlah & & $3,906.4$ \\
\hline
\end{tabular}

Sumber : Hasil Analisis Data Spasial, 2015

areal permukiman dengan luas 2,5 ha atau $0,2 \%$. Sedangkan pada 5 DAS dengan luas $>200$ ha juga didominasi oleh kebun campuran dengan luas 1236,2 ha atau $74,4 \%$ serta hutan dengan luas 424,5 ha atau $25,6 \%$. Secara keseluruhan tutupan lahan DAS di Pulau Seho di dominasi oleh kebun campuran dengan luas 3276,0 ha atau $83,9 \%$. Kemudian diikuti oleh kawasan hutan dengan luas 497,6 ha atau $12,7 \%$, serta hutan mangrove dengan luas 130,3 ha atau $3,3 \%$ dan areal pemukiman dengan luas 2,5 ha atau $0,1 \%$.

Kondisi topografi disetiap DAS di Pulau Seho sangat beragam, mulai dari daerah datar hingga berbukit dengan sudut kelerengan 0 $>40 \%$. dapat dilihat bahwa, ada perbedaan yang sangat besar pada setiap kelas lereng dari total 28 DAS. Dimana kelas lereng $15-25 \%$ memiliki total luas tutupan lahan adalah 1290,7 ha, yang terdiri dari luas hutan yaitu 176,2 ha $(4,5 \%)$, kebun campuran dengan luas 1114,1 ha $(28,5 \%)$, serta mangrove dengan luas 0,5 ha $(0,01 \%)$. Selanjutnya diikuti oleh kelas lereng $8-15 \%$ dengan total luas 1132,5 ha yang terdiri dari luas hutan 49,4 ha $(1,3 \%)$, kebun campuran 1076,5 ha $(27,6 \%)$, mangrove 6,6 ha $(0,2 \%)$. Kemudian kelas lereng $<8 \%$ dengan total luas yaitu 931,0 ha, yang terdiri hutan 123,2 ha $(3,2 \%)$, kebun campuran 805,3 ha $(20,6 \%)$, pemukiman 2,5 ha $(0,1 \%)$. Kemudian kelas lereng $25-40 \%$ dengan total luas 448,2 ha, yang terdiri dari hutan 202,0 ha $(5,2 \%)$, kebun campuran 246,3 ha $(6,3 \%)$. Serta kelas lereng $>40 \%$ dengan total luas 103,9 ha, yang terdiri dari hutan 71,5 ha $(1,8 \%)$, kebun campuran 32,4 ha $(0,8 \%)$.

DAS di Pulau Seho sebagian besar sudah mengalami kerusakan, akibat adanya kegiatan pembongkaran hutan yang dilakukan oleh masyarakat di sekitar kawasan hutan, baik untuk permukiman maupun untuk lahan pertanian. Kegiatan pembongkaran hutan tersebut telah mengakibatkan menurunnya luas hutan pada DAS Pulau Seho. Pawitan (2002) dan Asdak (2007) mengatakan bahwa Penurunan luas hutan akan berdampak terhadap menurunnya daya sangga air di kawasan DAS akibat rendahnya kapasitas infiltrasi. Agar fungsi DAS tetap terjaga maka pemerintah sudah seharusnya melakukan kerjasama dengan para stakeholders untuk melakukan penanaman pada setiap areal DAS yang sudah rusak akibat kegiatan pembongkaran hutan yang dilakukan oleh masyarakat.

\section{Model Zonasi Pengelolaan Pulau Seho.}

\section{Zona Inti}

Kawasan zona inti memiliki tutupan lahan berupa areal hutan yang terdapat pada bagian tengah dari Pulau Seho dan areal tidak berhutan. Kawasan zona inti memiliki topografi berupa daerah agak datar sampai daerah berbukit dengan ketinggian yaitu antara $0-250$ meter dari permukaan laut, dengan sudut kelerengan kawasan antara $0-40 \%$. Berdasarkan peta geologi, kawasan zona inti di dominasi oleh dua formasi batuan yaitu formasi Bobong yang mendominasi bagian timur dari zona inti atau tepat berada pada kawasan yang dominannya adalah areal hutan, serta formasi Salodik yang mendominasi bagian barat dari zona inti.

Hasil analisa peta zonasi pengelolaan hutan Pulau Seho, pada kawasan zona inti yang merupakan kawasan konservasi cagar alam terdapat 18 DAS dengan total luas 1463,9 ha. DAS yang ada pada kawasan zona inti memiliki tutupan lahan berupa hutan dengan luas 445,6 ha, dan kebun campuran dengan luas 1018,3 ha. Dari tabel 5.8 terlihat bahwa pada zona inti, kelas lereng $15 \%$ - 25\% menempati luasan terbesar yaitu 608,8 ha dan didominasi oleh kebun campuran dengan luas 446,9 ha, kemudian diikuti oleh kelas lereng $8 \%$ - $15 \%$ dengan luas 365,5 ha dan kelas lereng $25 \%$ - 40\% dengan luas 325,5 ha. Berdasarkan pengamatan di lapangan, areal hutan yang terdapat dalam zona inti didominasi oleh jenis-jenis kayu Meranti serta jenis Kayu lokal seperti kayu Hosa dan kayu Palapi. Jenis-jenis seperti kayu Meranti selalu dimanfaatkan oleh masyarakat yang ada dalam Pulau Seho baik 
Tabel 2. Luas Tutupan Lahan Pada Setiap Zonasi

\begin{tabular}{|c|c|c|c|c|c|c|c|}
\hline \multirow[b]{2}{*}{ Zona } & \multirow{2}{*}{$\begin{array}{c}\text { Kelas } \\
\text { Lereng } \\
(\%)\end{array}$} & \multicolumn{4}{|c|}{ Jenis Tutupan Lahan } & \multirow[b]{2}{*}{$\underset{(\mathrm{Ha})}{\text { Total }}$} & \multirow[b]{2}{*}{$\underset{\text { DAS }}{\text { Jumlah }}$} \\
\hline & & $\begin{array}{c}\text { Hutan } \\
\text { (Ha) }\end{array}$ & $\begin{array}{c}\text { Kebun } \\
\text { Campur } \\
\text { (Ha) }\end{array}$ & $\begin{array}{c}\text { Mangrove } \\
\text { (Ha) }\end{array}$ & $\begin{array}{c}\text { Pemu- } \\
\text { kiman } \\
\text { (Ha) }\end{array}$ & & \\
\hline \multirow{5}{*}{ Inti } & $<8$ & 0,0 & 61,8 & 0,0 & 0,0 & 61,8 & \multirow{5}{*}{18} \\
\hline & $8-15$ & 31,8 & 333,8 & 0,0 & 0,0 & 365,6 & \\
\hline & $15-25$ & 161,9 & 446,9 & 0,0 & 0,0 & 608,8 & \\
\hline & $25-40$ & 181,2 & 144,3 & 0,0 & 0,0 & 325,5 & \\
\hline & $>40$ & 70,8 & 31,6 & 0,0 & 0,0 & 102,4 & \\
\hline \multirow{5}{*}{ Penyangga } & $<8$ & 0,0 & 76,5 & 0,0 & 0,0 & 76,5 & \multirow{5}{*}{13} \\
\hline & $8-15$ & 17,6 & 234,4 & 0,0 & 0,0 & 252,0 & \\
\hline & $15-25$ & 14,3 & 225,5 & 0,0 & 0,0 & 239,8 & \\
\hline & $25-40$ & 20,8 & 57,6 & 0,0 & 0,0 & 78,4 & \\
\hline & $>40$ & 0,7 & 0,8 & 0,0 & 0,0 & 1,5 & \\
\hline \multirow{4}{*}{$\begin{array}{c}\text { Transisi/ } \\
\text { Rehabilitasi }\end{array}$} & $<8$ & 0,0 & $\begin{array}{l}667,0 \\
\end{array}$ & 123,2 & 2,5 & 792,8 & \multirow{4}{*}{20} \\
\hline & $8-15$ & 0,0 & 508,3 & 6,6 & 0,0 & 514,9 & \\
\hline & $15-25$ & 0,0 & 441,7 & 0,5 & 0,0 & 442,2 & \\
\hline & $25-40$ & 0,0 & 44,3 & 0,0 & 0,0 & 44,3 & \\
\hline
\end{tabular}

Sumber : Hasil Pengolahan Data Primer, 2015

untuk dijual maupun untuk memenuhi kebutuhan hidup mereka. Pemenuhan kebutuhan hidup masyarakat setiap hari mengakibatkan masyarakat mulai melakukan penebangan hutan yang sudah mulai masuk ke dalam areal kawasan cagar alam. Ini terlihat dari adanya bekas-bekas tebangan masyarakat yang sudah mulai masuk sampai melewati batas kawasan cagar alam.

Dengan demikian, penetapan zona inti yang berada langsung pada kawasan cagar alam bertujuan untuk melindungi dan menjaga keanekaragaman hayati yang ada dalam kawasan tersebut tetap lestari. Oleh karena itu, kerjasama antar pihak pengelola kawasan dan masyarakat perlu ditingkatkan agar potensi yang ada pada kawasan zona ini tidak diganggu oleh masyarakat sekitar kawasan hutan Pulau Seho.

\section{Zona Penyangga}

Zona penyangga adalah areal di sekeliling kawasan inti atau wilayah Cagar Alam. Luas zona penyangga yang ditetapkan adalah 664,64. Kawasan zona penyangga memiliki topografi berupa daerah agak datar sampai daerah berbukit dengan ketinggian yaitu antara $0-250$ meter dari permukaan laut, dengan sudut kelerengan kawasan antara $0-40 \%$. Berdasarkan peta geologi, kawasan zona penyangga ini di dominasi oleh dua jenis formasi batuan yaitu formasi bobong dan formasi salodik. Pada kawasan zona penyangga terdapat 13 DAS dengan total luas
648,3 ha. Kawasan zona penyangga didominasi oleh kebun campuran dengan luas 594,9 ha dan hutan dengan luas 53,4 ha. Pada zona penyangga ada 2 kelas lereng yang memiliki luasan terbesar yaitu kelas lereng $8 \%-15 \%$ dengan luas 252,0 ha dan kelas lereng 15\% - 25\% dengan luas 239,8 ha.

Hasil pengamatan di lapangan ditemukan bahwa salah satu bentuk pemanfaatan yang dilakukan oleh masyarakat di dalam kawasan zona penyangga adalah bentuk agroforestri tradisional, dengan kombinasi jenis-jenis tanaman perkebunan seperti cengkeh, pala, coklat dan jenis-jenis tanaman kehutanan seperti kayu meranti, damar, kayu hosa dan jenis kayu lainnya yang merupakan jenis-jenis yang selalu diman-faatkan oleh masyarakat untuk memenuhi kebutuhan hidup mereka. Pemenuhan kebutuhan ini akan membuat masyarakat sangat bergantung pada sumber daya yang ada pada kawasan zona penyangga.

Untuk mengurangi ketergantungan masyarakat pada sumber daya yang ada pada zona penyangga, maka pengelolaan zona ini harus dilakukan pada lahan milik masyarakat agar pengelolaannya dapat dilakukan dengan optimal. Berdasarkan kondisi biofisik kawasan, kondisi sosial ekonomi masyarakat sekitar, maka zona ini perlu dikelola dengan baik sehingga dapat meningkatkan perekonomian masyarakat. Salah satu bentuk pengelolaan yang baik yang perlu dilakukan pada kawasan zona penyangga yaitu 
pengelolaan agroforestri, dengan mengkombinasikan tanaman-tanaman pertanian dan perkebunan seperti tanaman cengkeh, kelapa serta coklat dengan tanaman kehutanan seperti kayu meranti (Shorea sp), damar (Aghatis sp) dan jenis kayu hosa (Lixe sp).

\section{Zona Transisi atau Zona Rehabilitasi}

Zona transisi/rehabilitasi merupakan areal di luar dari kawasan zona penyangga. Tutupan lahan pada zona transisi/rehabilitasi berupa kebun campuran, pemukiman masyarakat serta kawasan hutan mangrove yang ada pada bagian pesisir zona tersebut. Adapun kondisi geologi pada kawasan zona transisi/rehabilitasi yaitu jenis formasi bobong, formasi salodik, jenis aluvium serta jenis granit banggai. Di dalam kawasan zona transisi/rehabilitasi terdapat areal pemukiman masyarakat. Luas kawasan zona transisi/ rehabilitasi adalah 1758,36 ha. Kawasan zona transisi atau rehabilitasi memiliki topografi berupa daerah agak datar dengan ketinggian yaitu antara $0-200$ meter dari permukaan laut, dengan sudut kelerengan kawasan antara $0-40 \%$. Hasil pengamatan di lapangan menunjukan pada zona ini hampir sebagian besar kawasannya sudah bukan merupakan hutan melainkan areal kebun campuran.

Pada zona rehabilatasi/transisi sendiri terdapat 20 DAS. Tutupan lahan pada zona rehabilitasi/transisi didominasi oleh kebun campuran dengan luas 1661,3 ha, hutan mangrove dengan luas 130,3 ha. Di dalam kawasan zona rehabilitasi/transisi ada areal permukiman masyarakat suku terasing yang sudah tinggal di Pulau Seho sejak lama. Areal permukiman masyarakat ini seluas 2,5 ha dengan jumlah keluarga $\pm 20 \mathrm{KK}$. Kelas lereng $<8 \%$ dengan luas 792,8 ha menempati luas terbesar pada kawasan zona rehabilitasi/transisi. Kemu-dian diikuti oleh kelas lereng 8\% - 15\% dengan luas 514,9 ha, serta kelas lereng $15 \%$ $25 \%$ dengan luas 442,2 ha. Zona ini terdapat areal kebun masyarakat. namun, dalam kawasan tersebut juga terdapat areal bekas kebun masyarakat yang sudah tidak dipakai lagi dan hanya ditinggalkan begitu saja.

Kegiatan penanaman ulang pada areal hutan yang sudah rusak merupakan salah satu kegiatan yang perlu dilakukan pada kawasan zona rehabilitasi. Untuk itu, dalam kegiatan tersebut masyarakat perlu bersama-sama terlibat dengan semua pihak baik untuk kegiatan penanaman maupun kegiatan lainnya. Dengan adanya zona rehabilitasi, kawasan maupun ekosistem yang sudah rusak dapat dipulihkan dan kedepannya kawasan zona rehabilitasi dapat ditetapkan sebagai zona lainnya yang dapat mendukung kelestarian sumber daya yang ada pada kawasan hutan Pulau Seho serta dapat meningkatkan kesejahteraan masyarakat sekitar kawasan.

\section{Analisis Strategi Pengelolaan Hutan Pulau Seho}

Berdasarkan hasil pengolahan data pada matrik evaluasi faktor strategis internal dan eksternal, didapatkan besaran nilai dari masing-masing matrik, yang kemudian dimasukan kedalam analisa kuadran. Adapun nilai matrik evaluasi faktor strategis internal adalah sebesar 1,75 dan nilai matrik evaluasi faktor strategis eksternal adalah sebesar 1,95. Selanjutnya diperoleh hasil analisis kuadran seperti yang ditunjukkan pada Gambar 2.

Hasil analisis kuadran menunjukan nilai matriks evaluasi faktor internal dan eksternal berada pada kuadran 1. Ini berarti hutan Pulau Seho memiliki kekuatan dan peluang dalam pengelolaannya. Dengan demikian, strategi yang tepat dalam pengelolaan hutan Pulau Seho yaitu strategi yang menggunakan kekuatan untuk memanfaatkan peluang yang ada, sehingga dalam pengelolaan, strategi tersebut dapat mengatasi kelemahan serta dapat mengurangi ancaman yang ada pada hutan Pulau Seho.

\section{Matriks SWOT}

Berdasarkan hasil analisis faktor-faktor internal dan faktor-faktor eksternal, selanjutnya dilakukan analisis alternatif strategi pengelolaan hutan Pulau Seho dengan menggunakan matriks SWOT. Analisis dilakukan untuk melihat hubungan antara setiap indikator dari faktorfaktor internal dan eksternal, seperti yang ditunjukkan pada Tabel 3.

\section{Strategi Pengelolaan Kawasan Hutan Pulau Seho}

\section{Melakukan pengelolaan kolaborasi bersa- ma pemerintah dan masyarakat sekitar}

Pengelolaan kolaborasi merupakan salah satu strategi yang tepat dalam melakukan pengelolaan hutan lestari. Pengelolaan kolaborasi dimaksudkan untuk mencegah terjadinya konflik yang bisa terjadi antara pemerintah dan masyarakat. Dalam Permenhut Nomor P.19 /Menhut-II/2004, pengelolaan kolaborasi KSA dan KPA dapat dilakukan dengan melibat-kan partisipasi masyarakat. Kerjasama antara masyarakat sekitar dengan pemerintah akan 


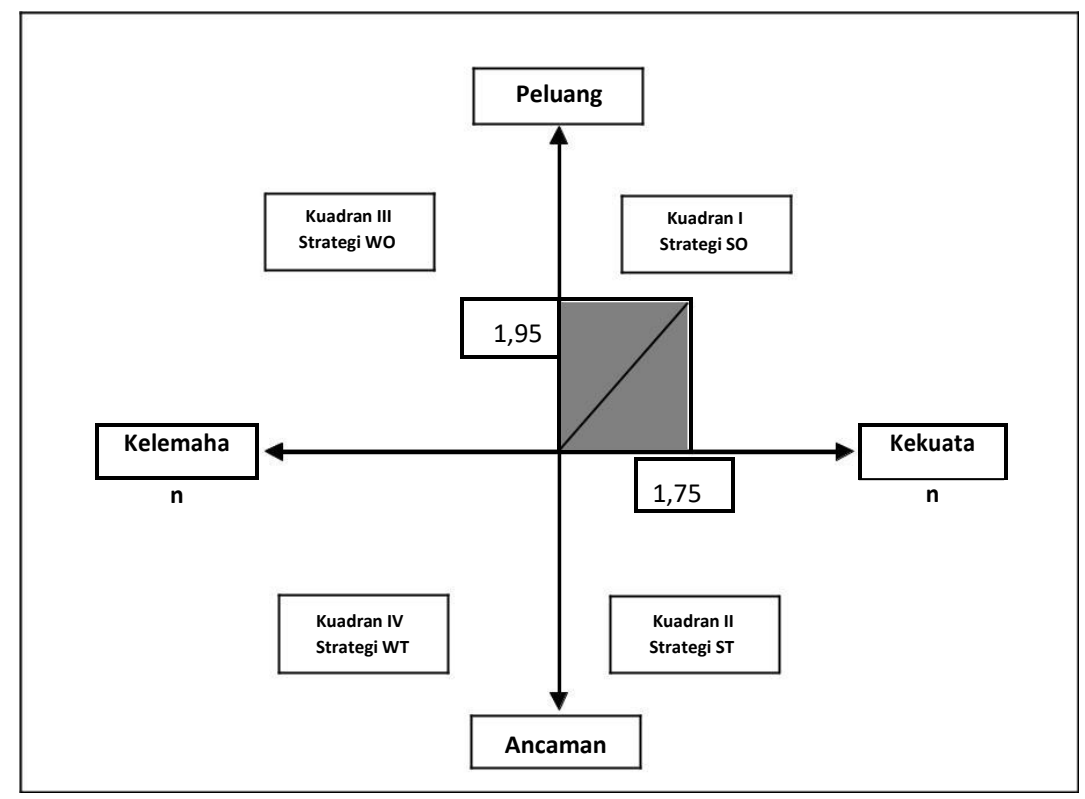

Gambar 2. Hasil Analisis Kuadran

memberikan peluang terjadinya konflik menjadi sangat kecil. Hal ini karena kerjasama masyarakat dengan pemerintah dalam suatu kolaborasi akan memberikan pemahaman kepada masyarakat bahwa masyarakat merupakan bagian dari kegiatan pengelolaan hutan.

Dengan demikian, dalam kegiatan pengelolaan hutan, kerjasama antara pemerintah dan masyarakat akan sangat mendukung untuk mencapai keberhasilan pengelolaan hutan. Untuk itu, kegiatan-kegiatan yang terkait dengan pengelolaan hutan Pulau Seho, baik itu kegiatan penyusunan rencana pengelolaan kawasan, pengambilan keputusan, perlindungan dan pengamanan kawasan harus melibatkan masyarakat sekitar kawasan hutan Pulau Seho.

\section{Pelibatan masyarakat sebagai tenaga peng-awas untuk mengawasi dan mengamankan kawasan hutan Pulau Seho}

Keberadaan masyarakat di sekitar kawasan hutan sudah merupakan tolak ukur dalam mencapai kelestarian suatu kawasan. Hal ini karena masyarakat selalu melakukan aktifitas seperti berkebun, menebang pohon serta berburu. Aktifitas masyarakat seperti ini jika kurang diawasi maka akan sangat mempengaruhi keberadaan potensi sumber daya hayati yang ada dalam kawasan hutan.

Oleh karena itu, pelibatan masyarakat sebagai tenaga pengawas dan pengamanan kawasan hutan Pulau Seho serta kawasan cagar alam merupakan salah satu strategi yang perlu diterapkan. Strategi ini dianggap perlu karena dengan adanya masyarakat sebagai tenaga pengawas dan pengamanan kawasan aktifitas masyarakat dalam merusak hutan akan menurun. Hal tersebut dikarenakan masyarakat akan memiliki tanggung jawab yang besar untuk menjaga kelestarian hutan. salah satu kegiatan yang perlu dilakukan oleh masyarakat sebagai tenaga pengawas dan pengamanan kawasan yaitu melakukan patrol rutin dalam mengawasi dan mengamankan kawasan hutan.

\section{Melakukan kegiatan pengelolaan hutan berbasis masyarakat adat dengan pende- katan Agroforestri}

Pengelolaan hutan di Indonesia sampai saat ini masih belum jelas menunjukan hak kepemilikan lahan. Konflik yang terjadi antara masyarakat dengan pemerintah maupun dengan pengusaha dibidang kehutanan menjadi persoalan yang timbul akibat adanya klaim atas hak kepemilikan lahan. Seperti halnya dengan pengelolaan hutan di Indonesia, pengelolaan hutan di Pulau Seho juga tidak terlepas dari permasalahan kepemilikan hak atas lahan. Hal ini dapat terlihat dari adanya lahan yang dianggap sebagai lahan adat milik masyarakat adat yang ada di Pulau Seho. Oleh karena itu pengelolaan hutan berbasis masyarakat adat merupakan salah satu strategi yang perlu dicapai untuk pengelo-laan hutan lestari.

Agroforestri merupakan salah satu bentuk pengelolaan yang tepat untuk mengurangi permasalahan tersebut. Agroforestri merupakan bentuk pengelolaan hutan dengan mengkom- 
Tabel 3. Hasil Analisis SWOT

\begin{tabular}{|c|c|c|}
\hline Eksternal & $\begin{array}{l}\text { Kekuatan (S) } \\
\text { a. Adanya Kawasan Cagar Alam } \\
\text { Pulau Seho } \\
\text { b. Potensi kayu masih cukup baik } \\
\text { c. Merupakan hutan hujan tropis } \\
\text { dataran rendah } \\
\text { d. Merupakan wilayah paling } \\
\text { barat dari sebaran jenis Matoa } \\
\text { (Pometia pinnata) } \\
\text { e. Adanya kekhasan dan } \\
\text { kelangkaan spesies flora dan } \\
\text { fauna } \\
\text { f. Adanya kawasan ekosistem } \\
\text { hutan mangrove } \\
\text { g. Adanya tenaga pengawas } \\
\text { kawasan konservasi }\end{array}$ & $\begin{array}{l}\text { Kelemahan (W) } \\
\text { a. Hasil hutan kayu belum } \\
\text { dimanfaatkan dengan baik } \\
\text { b. Kurangnya kegiatan } \\
\text { pengawasan kawasan } \\
\text { konservasi } \\
\text { c. Infrasturktur pengelolaan } \\
\text { belum memadai } \\
\text { d. Kapasitas tenaga pengawas } \\
\text { rendah } \\
\text { e. Pendidikan masyarakat } \\
\text { masih rendah } \\
\text { f. Rendahnya kesadaran } \\
\text { masyarakat dalam menjaga } \\
\text { hutan } \\
\text { g. Penegakan hukum lemah } \\
\text { h. Pendapatan masyarakat } \\
\text { tergolong rendah }\end{array}$ \\
\hline $\begin{array}{l}\text { Peluang (O) } \\
\text { a. Adanya dukungan } \\
\text { pemerintah daerah } \\
\text { b. Adanya tenaga pengawas } \\
\quad \text { kawasan konservasi } \\
\text { c. Adanya masyarakat adat } \\
\text { d. Kemauan masyarakat dalam } \\
\text { menjaga kelestarian hutan } \\
\text { e. Pengetahuan masyarakat } \\
\text { tentang hutan lindung } \\
\text { f. Sistem agroforestri }\end{array}$ & $\begin{array}{l}\text { Strategi (SO) } \\
\text { a. Melakukan pengelolaan } \\
\text { kolaborasi bersama pemerintah } \\
\text { dan masyarakat sekitar } \\
\text { b. Pelibatan masyarakat sebagai } \\
\text { tenaga pengawas untuk } \\
\text { mengawasi dan mengamankan } \\
\text { hutan pulau Seho } \\
\text { c. Melakukan kegiatan } \\
\text { pengelolaan hutan berbasis } \\
\text { masyarakat adat dengan } \\
\text { pendekatan agroforestri } \\
\text { d. Meningkatkan pengetahuan dan } \\
\text { kesadaran masyarakat tentang } \\
\text { konservasi melalui kegiatan } \\
\text { penyuluhan kehutanan } \\
\text { e. Meningkatkan sumber daya } \\
\text { manusia melalui program } \\
\text { pemberdayaan masyarakat } \\
\end{array}$ & $\begin{array}{l}\text { Strategi (WO) } \\
\text { a. Bekerjasama dengan } \\
\text { pemerintah untuk } \\
\text { meningkatkan pengetahuan } \\
\text { masyarakat tentang } \\
\text { pengelolaan dan } \\
\text { pemanfaatan hasil hutan } \\
\text { b. Perbaikan infrastruktur } \\
\text { pengelolaan, peningkatan } \\
\text { tenaga pengawas dan } \\
\text { penegakan hukum } \\
\text { c. Tingkatkan ekonomi } \\
\text { masyarakat dengan } \\
\text { menerapkan pengelolaan } \\
\text { agroforestri }\end{array}$ \\
\hline $\begin{array}{l}\text { Ancaman (T) } \\
\text { a. Akses masyarakat yang } \\
\text { mudah } \\
\text { b. Kegiatan pembongkaran } \\
\quad \text { hutan yang dilakukan oleh } \\
\text { masyarakat } \\
\text { c. Perladangan berpindah } \\
\text { d. Perburuan satwa liar } \\
\text { e. Penebangan liar } \\
\text { f. Pengambilan kayu sebagai } \\
\text { bahan bakar } \\
\text { g. Bekas areal HPH }\end{array}$ & $\begin{array}{l}\text { Strategi (ST) } \\
\text { a. Menyiapkan dan memberikan } \\
\text { data dan informasi kawasan } \\
\text { konservasi kepada masyarakat } \\
\text { b. Penyuluhan kepada masyarakat } \\
\text { tentang pentingnya kelestarian } \\
\text { sumber daya hutan } \\
\text { c. Peningkatan dan pemanfaatan } \\
\text { tenaga pengawas untuk } \\
\text { mengawasi kawasan hutan guna } \\
\text { mencegah dan mengurangi } \\
\text { aktifitas masyarakat yang dapat } \\
\text { merusak hutan } \\
\end{array}$ & $\begin{array}{l}\text { Strategi (WT) } \\
\text { a. Melibatkan masyarakat } \\
\text { dalam rencana pengelolaan } \\
\text { kawasan hutan } \\
\text { b. Peningkatan pendidikan atau } \\
\text { pelatihan kepada masyarakat } \\
\text { c. Memberikan pemahaman } \\
\text { kepada masyarakat tentang } \\
\text { pemanfaatan hasil hutan }\end{array}$ \\
\hline
\end{tabular}


binasikan tanaman kehutanan dan tanaman pertanian. Masyarakat sekitar kawasan hutan Pulau Seho pada umumnya memanfaatkan hasil hutan berupa kayu hosa, kayu meranti . Sedangkan hasil pertanian yang dimanfaatkan berupa buah-buahan, cengkeh, coklat dan kelapa. Dengan demikian sistem agroforestri yang dapat dilakukan pada kawasan hutan Pulau Seho adalah dengan mengkombinasikan jenis-jenis kayu kehutanan seperti kayu hosa dan kayui meranti serta jenis tanaman pertanian seperti cengkeh, coklat dan kelapa yang dipadu dengan jenis buahbuahan seperti langsat dan duku.

Penerapan pengelolaan agroforestri pada kawasan hutan Pulau Seho, jika dilihat dari aspek ekonomi, sistem agroforestri dapat meningkat-kan pendapatan masyarakat sekitar. Sedangkan dari aspek ekologi, kelestarian hutan dapat terjaga karena adanya starta pertumbuhan yang tercipta dari bentuk atau sistem agroforestri yang diterapkan.

\section{Meningkatkan pengetahuan dan kesadaran masyarakat tentang konservasi melalui kegiatan penyuluhan}

Minimnya tingkat pendidikan akan sangat mempengaruhi pengetahuan dan kesadaran masyarakat tentang pentingnya perlindungan kawasan hutan. Strategi untuk meningkatkan pengetahuan dan kesadaran masyarakat sekitar kawasan hutan akan sangat menguntukan dalam program perlindungan kawasan hutan. Kegiatan penyuluhan merupakan salah satu cara untuk meningkatkan pengetahuan dan kesadaran masyarakat tentang konservasi. Penyuluhan perlu dilakukan dengan tujuan untuk memberikan informasi bagi masyarakat tentang konservasi dengan melibatkan berbagai elemen masyarakat agar mereka dapat memahami dan mau mengembangkan pengetahuan mereka guna menjaga dan melestarikan hutan dan sumber dayanya.

\section{Meningkatkan sumber daya manusia melalui program pemberdayaan masyarakat}

Pemberdayaan masyarakat untuk meningkatkan sumber daya manusia dalam mengelola sumber daya hutan sangat diperlukan. Hal ini bertujuan untuk mengurangi ketergantungan masyarakat terhadap sumber daya yang ada. Dalam kegiatan pemberdayaan masyarakat, peran pemerintah sangat diharapkan untuk membantu keberhasilan program tersebut.

Beberapa program pemberdayaan masyarakat yang dapat dilakukan untuk meningkatkan sumber daya manusia dalam mengelola sumber daya hutan yaitu dengan meningkatkan pendidikan dan memberikan pelatihan kepada masyarakat sekitar serta memberikan peluang usaha alternatif bagi masyarakat untuk mengurangi pemanfaatan sumber daya hutan yang berlebihan. Dengan adanya program pemberdayaan masyarakat, kedepannya masyarakat dapat memanfaatkan dan meningkatkan kemampuan mereka untuk mengelola sumber daya alam guna meningkatkan taraf hidup mereka.

\section{Analisis Matriks QSPM}

Berdasarkan hasil perhitungan QSPM, diketahui bahwa prioritas strategi yang dapat diterapkan dalam pengelolaan hutan Pulau Seho adalah :

1. Melakukan pengelolaan kolaborasi bersama pemerintah dan masyarakat sekitar $(6,05)$.

2. Pelibatan masyarakat sebagai tenaga pengawas untuk mengawasi dan mengamankan hutan Pulau Seho $(5,28)$.

3. Meningkatkan pengetahuan dan kesadaran masyarakat tentang konservasi melalui kegiatan penyuluhan kehutanan $(4,86)$.

Tabel 4. Hasil Pemeringkatan Matriks Perencanaan Strategi Kuantitatif (QSPM)

\begin{tabular}{clc}
\hline Nomor & \multicolumn{1}{c}{ Alternatif Strategi } & TAS \\
\hline 1 & $\begin{array}{l}\text { Melakukan pengelolaan kolaborasi bersama pemerintah dan } \\
\text { masyarakat sekitar }\end{array}$ & 6,05 \\
\hline 2 & $\begin{array}{l}\text { Pelibatan masyarakat sebagai tenaga pengawas untuk mengawasi } \\
\text { dan mengamankan hutan pulau Seho }\end{array}$ & 5,28 \\
\hline 3 & $\begin{array}{l}\text { Melakukan kegiatan pengelolaan hutan berbasis masyarakat adat } \\
\text { dengan pendekatan agroforestri }\end{array}$ & 4,80 \\
\hline 4 & $\begin{array}{l}\text { Meningkatkan pengetahuan dan kesadaran masyarakat tentang } \\
\text { konservasi melalui kegiatan penyuluhan kehutanan }\end{array}$ & 4,86 \\
\hline 5 & $\begin{array}{l}\text { Meningkatkan sumber daya manusia melalui program } \\
\text { pemberdayaan masyarakat }\end{array}$ & 4,48 \\
\hline
\end{tabular}


4. Melakukan kegiatan pengelolaan hutan berbasis masyarakat adat dengan pendekatan agroforestri $(4,80)$.

5. Meningkatkan sumber daya manusia melalui program pemberdayaan masyarakat $(4,48)$.

\section{KESIMPULAN}

1. Kawasan hutan Pulau Seho memiliki potensi keanekragaman hayati yang masih cukup baik dan khas, dan merupakan endemik. Potensi tersebut dapat dikelola dan dikembangkan untuk meningkatkan kesejahteraan masyara-kat sekitar kawasan hutan Pulau Seho, serta meningkatkan PAD Kabupaten Pulau Taliabu.

2.Hasil overlay peta tutupan lahan, peta kelerengan, peta ketinggian, peta DAS dan peta zonasi, ditemukan 28 DAS pada Pulau Seho. Dari 28 DAS, terdapat :

a. 11 DAS dengan luas $<100$ ha memiliki tutupan lahan adalah kebun campuran dengan luas 582,1 ha atau sebesar 91,6\% dan hutan mangrove dengan luas 53,3 ha atau sebesar $18,4 \%$.

b. 12 DAS dengan luas $100-200$ ha didominasi oleh kebun campuran dengan luas 1457,72 ha atau $90,5 \%$, hutan dengan luas 73,1 ha atau $4,5 \%$ serta hutan mangrove dengan luas 77,0 ha atau $4,8 \%$, areal permukiman dengan luas 2,5 ha atau $0,2 \%$.

c. 5 DAS dengan luas $>200$ ha didominasi oleh kebun campuran dengan luas 1236,2 ha atau $74,4 \%$, hutan dengan luas 424,5 ha atau $25,6 \%$.

3. Hasil analisis SWOT dan hasil perhitungan QSPM, diperoleh beberapa alternatif dan prioritas strategi yang dapat diterapkan dalam pengelolaan kawasan hutan Pulau Seho, sebagai berikut :Melakukan pengelolaan kolaborasi bersama pemerintah dan masyarakat sekitar $(6,05)$,

a. Pelibatan masyarakat sebagai tenaga pengawas untuk mengawasi dan menga-mankan kawasan hutan Pulau Seho $(5,28)$,

b. Meningkatkan pengetahuan dan kesadaran masyarakat tentang konservasi melalui kegiatan penyuluhan kehutanan $(4,86)$.

c. Melakukan kegiatan pengelolaan hutan berbasis masyarakat adat dengan pendekatan agroforestri $(4,80)$.

d. Meningkatkan sumber daya manusia melalui program pemberdayaan masyara-kat $(4,48)$.

\section{DAFTAR PUSTAKA}

Asdak, C., 2002. Hidrologi dan Pengelolaan Daerah Aliran Sungai. Ed ke 2. Gajah Mada University Press. Yogyakarta.

Kastanya, A., 2006. Konsep Pengelolaan Hutan Lestari Pulau-Pulau Kecil Berbasis Ekosistem Dan Masyarakat Di Kepulauan Maluku. Prosiding Workshop Program Kehutanan Nasional "Perencanaan Pembangunan Kehutanan Berbasis Ekosistem Pulau Kecil". www. irwantoshut.com [7 November 2013].

Oszaer, R., 2006. Permasalahan Hutan Dan Kehutanan Di Maluku Dan Maluku Utara.

PROSIDING WORKSHOP PROGRAM KEHUTANAN NASIONAL "Perencanaan Pembangunan Kehutanan Berbasis Ekosistem Pulau Kecil”. www. irwantoshut.com [7 November 2013].

Pawitan, H., 2002. Tinjauan Penelitian Perubahan Penggunaan Lahan Di Daerah Aliran Sungai Cijalupang. Paper dalam Konfe-rensi Hidrologi di Balai Penelitian Tanah. Bogor.

Rangkuti, F., 2002. Analisis SWOT Teknik Membedah Kasus Bisnis. PT. Gramedia Pustaka Utama, Jakarta

Siregar, N., Chairil., 2008. Analisis Potensi Daerah Pulau-Pulau

Terpencil Dalam Rangka Meningkatkan Ketahanan, Keamanan Nasional, Dan Keutuhan Wilayah NKRI Di NunukanKalimantan Timur. Jurnal Sosioteknologi Edisi 13 Tahun 7, April 2008. 